In 1928 appeared, as vol. $\mathrm{xxx}$ of the New Series of the Oriental Translation Fund the Zoological Section of the Nuzhatu-l-Qulub of Hamdulla al-Mustaufi, edited, translated, and annotated by Colonel Stephenson. This also was begun from a lithographed copy obtained in India, later collated with six manuscripts in Europe. A full review of this work, by Professor Nicholson, appeared in the Society's JouRNaL in January, 1930, to which I can only add an expression of the debt due to the author from those interested in the history of medicine.

Several reviews by Colonel Stephenson in the JouRNaL are not only admirable in themselves, but demonstrate what manner of man the writer was and bear witness to his scientific insight, his philosophy, and his intense interest in humanity in all climes and ages. These were all essential parts of him, but perhaps those who were privileged to call themselves his friends will remember, with the keenest sense of loss, his innate courtesy and kindness and his understanding sympathy.

G. MacI. C. Smith.

\title{
Professor A. H. Sayce
}

An admirable account of the life and work of Professor Sayce was printed in the Times of 6th February, and an interesting estimate of his career in Oxford by colleagues at Queen's in The Oxford Magazine of 16th February. Having been asked by the President and Council to contribute an obituary notice of the great Orientalist to the JournaL of the Royal Asiatic Society, I have chosen to turn rather to personal reminiscences and impressions covering half a century.

I well remember my first meeting with Sayce, the hesitating climb up the college stairs and the tap at his door, immediately answered by the great man himself, who conducted me to a chair with charming courtesy and eventually invited me to 
a breakfast where the chief guest was a promising young Assyriologist, S. A. Smith. Smith, to our grief and amazement, disappeared after publishing a few Cuneiform texts.

I held a scholarship at Sayce's own College-Queen'sand I was afterwards told that it was his judgment of my essay in the examination that led to my election. The subject set was "How far is inconsistency a merit?" and in my untutored way I upheld the merit of inconsistency and quoted the Archæopteryx as an instance of inconsistency in nature. From subsequent experience, I feel sure that Archæopteryx was the winning hit. A little interest in outside knowledge counted for more than the most precise information on the uses of $\ddot{a} \nu$.

Sayce was always a pessimist in regard to humanity and held that in England there was no career for unorthodox scholarship or research. In my case this point was settled favourably by kind friends and by the Egypt Exploration Fund with Flinders Petrie.

Sayce, as everyone knows, used to travel in Egypt annually, and after inspecting the progress of exploration in all parts of the Mediterranean region wrote a letter to the Academy on what he had seen and the conclusions he had drawn. To those who had borne the burden and heat of excavation it was a mixed pleasure to see its results gathered and estimated by a passing visitor, however much knowledge and acumen accompanied the statement. Too often Sayce's conclusions were vitiated by over-hasty views. He carried with the utmost ease a vast weight of various and peculiar learning, and could concentrate all this on any particular point that came up for valuation, while his vivid imagination could draw sharply defined conclusions from the data; unfortunately, before he had tested his evidence and conclusions, his attention was too easily diverted to other matters within his vast range of interests. In short, his critical faculty was inferior to his other gifts. In spite of weak lungs and weak eyes, he read enormously and accomplished a vast amount of writing; 
besides popularizing research, Sayce effected decipherments of great importance in several directions and pointed out for the first time historical facts of a revolutionary character. Unfortunately he made the Higher Critics of the Bible the principal butt for attack, and it must be confessed that here he actually sacrificed research and scholarship to a fleeting popularity. The truth prevails and must prevail.

Professor Sayce joined the Royal Asiatic Society in 1874, and contributed to its JourNaL some of his finest work. Especial mention must be made of his treatise on the tenses of the Assyrian verb (1877) and his triumphant decipherment of the Vannic inscriptions from 1882 onward. Down to the time of his death he was writing reviews and articles for the Jounnal. At that time there survived only one member who was senior to him. He served long on the Council, and in 1925 the Society awarded to him its triennial gold medal. The Society of Biblical Archæology, however, of which he was President for many years, claimed his most constant service from its foundation in 1872 to its absorption by the Royal Asiatic Society in 1919.

F. Ll. Griffith.

\section{Archibald Henry Sayce as Assyriologist}

Dr. A. H. Sayce, Emeritus Professor of Assyriology at Oxford, was a Welshman of distinguished and aristocratic lineage. His father held a living in Monmouthshire, but the family was long attached to Bristol, where his great grandfather built Clifton House under the tower of Clifton Church.

His early youth was marked by remarkable precocity. He was reading Homer and Virgil at the age of ten, and before he entered Queen's College, Oxford, at the age of 18 he had read some Egyptian, Hebrew, Sanskrit, and the discoveries of Grotefend, Rawlinson, Hincks, and Oppert. An article on the decipherment of the Persian and Babylonian versions of 